\title{
TU/e EmonOWEN

\section{A special issue on bone biomechanics, dedicated to F. Gaynor Evans, editor emeritus}

Citation for published version (APA):

Huiskes, H. W. J. (1987). A special issue on bone biomechanics, dedicated to F. Gaynor Evans, editor emeritus. Journal of Biomechanics, 20(11-12), 1013-. https://doi.org/10.1016/0021-9290(87)90016-9

DOI:

10.1016/0021-9290(87)90016-9

Document status and date:

Published: 01/01/1987

\section{Document Version:}

Publisher's PDF, also known as Version of Record (includes final page, issue and volume numbers)

\section{Please check the document version of this publication:}

- A submitted manuscript is the version of the article upon submission and before peer-review. There can be important differences between the submitted version and the official published version of record. People interested in the research are advised to contact the author for the final version of the publication, or visit the $\mathrm{DOI}$ to the publisher's website.

- The final author version and the galley proof are versions of the publication after peer review.

- The final published version features the final layout of the paper including the volume, issue and page numbers.

Link to publication

\section{General rights}

Copyright and moral rights for the publications made accessible in the public portal are retained by the authors and/or other copyright owners and it is a condition of accessing publications that users recognise and abide by the legal requirements associated with these rights.

- Users may download and print one copy of any publication from the public portal for the purpose of private study or research.

- You may not further distribute the material or use it for any profit-making activity or commercial gain

- You may freely distribute the URL identifying the publication in the public portal.

If the publication is distributed under the terms of Article 25fa of the Dutch Copyright Act, indicated by the "Taverne" license above, please follow below link for the End User Agreement:

www.tue.nl/taverne

Take down policy

If you believe that this document breaches copyright please contact us at:

openaccess@tue.nl

providing details and we will investigate your claim. 


\section{EDITORIAL}

\section{A SPECIAL ISSUE ON BONE BIOMECHANICS, DEDICATED TO F. GAYNOR EVANS, EDITOR EMERITUS}

On 7 December, in the publication month of this issue, Volume 20. Number 11,12 , F. Gaynor Evans, Editor Emeritus of the Journal of Biomechanics, celebrates his 80th Birthday. Following a suggestion from Andrus Viidik. we join in the celebration with this Special Issue. dedicated to him.

F. Gaynor Evans became Co-Editor-in Chief when the Journal was founded in 1967, and he held that position from Volume 1 , in 1968, to Volume 12 , Number 8 , in August 1979. For almost 12 years he was responsible, together with Verne L. Roberts, for its tremendous success.

Of course, the subject of this issue is Bone Biomechanics. Evans" contributions to this field, in a lifetime of dedicated research, are known to virtually anybody even slightly interested in this subject. His books have become classics, and his articles are widely read throughout the world. You will find evidence of that in this issue.

With the assistance of our Guest Editors for this special occasion, John D. Currey, Dennis R. Carter, and Andrus Viidik, we attracted a number of authors specialized in Bone Biomechanics to submit a manuscript and work with us through the review procedure in a tight schedule. Their commission was to compose either a personalized review, or a rescarch paper, based on original data, blended with personal philosophies about future research directions. The result is not a complete overview of present-day research in Bone Biomechanics, but a kaleidoscope, a collection of differently flavored contributions from several sub- areas, together giving a tasty and thought-provocative impression of the state-of-the-art.

This issue is special in more than one sense. It closes the 20th Volume, which can be considered another Anniversary. Primarily responsible for its editorial management during those 20 years, was our Founding Editor, Verne L. Roberts. With regret I must announce that he will retire from his position as CoEditor-in-Chief by the end of this year. Hence, this is the last issue under his responsibility. This will be a great loss for the Journal, but after 20 years of active and successful service, we can only respect his decision. He will be succeeded by Richard A. Brand. from lowa City, U.S.A. who is known to many of our readers through his research and his previous position as Book Review Editor. In the next issue, Volume 21, Number 1, we will come back to this 'changing of the guards'. We have new plans, for the contents of the Journal and for its editorial organization. but you must wait another month to be fully informed.

Finally, returning to the dedication of the present issue, dear Gaynor, on behalf of the Journal of Biomechanics, I wish you a Happy Birthday. We are glad to hear that you are well and enjoying your life's winter season as intensely as you have enjoyed your research work. Reading through this issue, it is quite obvious that you are the father of modern Bone Biomechanics, and we are your offspring. I trust you are proud of us.

RIK HUISKES

Co-Editor-in-Chief 